\title{
REPEATABILITY REVEALS TO BE A USEFUL METHOD TO EVALUATE THE QUALITY OF AN EXPERIMENT WITH COMMON BEANS
}

\author{
REPETIBILIDADE REVELA SER UM MÉTODO EFICIENTE PARA AVALIAR \\ A QUALIDADE DE EXPERIMENTOS EM FEIJÃO
}

\author{
Fábio de Lima GURGEL ${ }^{1}$; Leonardo de Azevedo PEIXOTO² ${ }^{2}$ Leonardo Lopes BHERING $^{2}$; \\ Bruno Galvêas LAVIOLA ${ }^{3}$
}

1. Embrapa Amazônia Oriental, Belém, PA, Brazil; 2. Biology Department, Universidade Federal de Viçosa, Viçosa, MG, Brazil; 3. Empresa Brasileira de Pesquisa Agropecuária, Brasília, Brasil. leoazevedop@ gmail.com

\begin{abstract}
Field experiment should be carried out with high accuracy since the discarding of a trial involves waste of time and resources, and can mislead breeders in selecting inferior genotypes. The simulation of a large number of experiments with great variability of traits is the main strategy to assist breeders on how to perform the experiment. Therefore, the objective of this study was to evaluate two criteria to infer the experimental quality: Coefficient of Variation (CV) and repeatability coefficient. Experimental data from evaluations of common bean lines carried out in 104 experiments were used in this study. The simulation of the scenarios used the following parameters: number of cultivars, number of blocks, genetic variance, mean yield, and coefficient of variation. Two thousand replications for each scenario were simulated. Genotypes means were arranged in an order, and the Spearman correlation was obtained between the estimated genotypes mean and the true genotypic values. Results revealed that $\mathrm{CV}$ is not a reliable parameter to evaluate the quality of experiment in the field. In conclusion, repeatability coefficient is the parameter that defines the discarding criteria of evaluation experiments and the recommendation of cultivars, as long as the values for each response variable are established.
\end{abstract}

KEY WORDS: Phaseolus vulgaris. Cultivars. Experimental accuracy. Statistics methods

\section{INTRODUCTION}

The Brazilian production of common beans (Phaseolus vulgaris) in the 2015/2016 season was of 3.33 million tons in a cultivated area of 3.02 million hectares (CONAB, 2016). In common beans, grain yield is highly correlated with yield components: number of plants, number of pods per plant, number of grains per plant, and grain mass (ZILIO et al., 2011). Depending on the climate conditions, some yield components may increase and others may decrease, which facilitates the maintenance of yield stability (CASQUERO et al., 2006). These changes in the expression of the traits are attributed to environmental factors that interfere with genotype expression.

To improve the experimental accuracy, the researcher must plan, perform, and analyze the data in a proper manner. Therefore, approaches on the sources of experimental error, i.e., sources that cause variability between the observations on experimental units in the same treatment, and the use of appropriate experimental techniques have been extensively described in the literature (RAMALHO et al., 2005).

The publication of accuracy indicators, obtained based on the largest possible number of similar experiments, is necessary for the evaluation of the research quality. Storck et al. (2000) reported that the distribution of the coefficients of variation values $(\mathrm{CV})$ can help breeders to decide about discarding experiments.

The Plant Variety Protection Law (number 9456) states that experiments with $\mathrm{CV}$ equal to or less than $20 \%$ should be considered. This criterion is used for soybean and corn crops (CARGNELUTTI FILHO; STORCK, 2009: OLIVEIRA et al., 2009: CARGNELUTTI FILHO; GONÇALVES, 2011).

$\mathrm{CV}$ evaluation has been carried out by several authors, who used different methods for the determination of experimental techniques in different cultures (MARTIN et al., 2005: OLIVEIRA et al., 2006: LIMA et al., 2007: CATAPATTI et al., 2008). Oliveira et al. (2009) studied the distribution of $\mathrm{CV}$ values of common bean crops and proposed ranges that guide researchers in the experiment evaluation. To this, the authors calculated the $\mathrm{CV}$ ranges for yield, number of pods per plant, number of grains per pod, 100-grain weight, final stand, plant height, and harvest index. Results indicated that ranges of CV values differ between the variables and present wide variation, which justifies the use of evaluation range specific for each variable.

Field experiment should be carried out with high accuracy, since the discarding of experiment is time- and cost-consuming, and can mislead breeders in selecting the wrong genotypes. Simulation may 
be suitable strategy to help breeders on how to carry out field experiments by simulating a large number of trials, with great variability of traits. The aim of this study was to verify the suitability of coefficient of variation (CV) as a criterion to discard experiment; to estimate the confidence interval of $\mathrm{CV}$ to discard experiments; and to check if repeatability is an option to increase experiment efficiency.

\section{MATERIAL AND METHODS}

To define at which interval the parameters should be simulated, experimental data from multiple years and locations were used based on meta-analysis previously performed. Data of common bean lines evaluated by UFLA/EPAMIG during 11 years (1991-2001) were used, totaling 104 experiments. To determine the most important variables and the limits to be used in the simulation, a survey was initially carried out with some common bean experimental data (Table 1).

Several variables were simulated based on the data shown in the table, aiming to infer and evaluate these variables under different experimental conditions. Experiments were simulated in randomized block designs with 3 replications. The following parameters and their respective values were used: number of cultivars $(25,30$ and 36$)$, genetic variance $(5,000 ; 7,500$; 12,$500 ; 15,000 ; 22,500 ; 37,500 ; 35,000 ; 52,500$; and $87,500)$, mean yield in $\mathrm{kg} / \mathrm{ha}(1.000,1.500$ and $2.500)$, and coefficient of variation (CV) $(5,10,15$, 20, 30, 50, 70, 90 and 100\%).

Table 1. Information used as references for parameters simulation for common beans (Phaseolus vulgaris).

\begin{tabular}{cccc}
\hline Parameters & Minimum & Mean & Maximum \\
\hline Number of cultivars & 25 & - & 36 \\
Number of blocks & - & 3 & - \\
Genetic variance & 2650 & 16441 & 65813 \\
Mean Yield (kg/ha) & 517 & 897 & 1444 \\
$\mathrm{CV}^{(1)}(\%)$ & 15 & - & 24 \\
\hline
\end{tabular}

${ }^{(1)}$ Coefficient of Variation

Monte Carlo simulation was used to evaluate the criteria for experiment discard. Two thousand replications for each combination of the parameters mentioned above were simulated, totaling 729 scenarios. All these data were processed by a computer software developed in an environment of Delphi programming.

Field experiment were simulated considering a complete randomized block design (CRB) with the following statistical model:

$Y_{i j}=\mu+g_{i}+b_{j}+e_{i j}$

Being: and block $\mathrm{j}$;

$Y_{i j}$ : the observation of the plot in treatment $\mathrm{i}$

$\mu$ : the general mean of experiment;

$\mathrm{b}_{\mathrm{j}}$ : the block effect with $\mathrm{b}_{\mathrm{j}} \sim \mathrm{NID}\left(0, \sigma_{b}^{2}\right)$

$\mathrm{g}_{\mathrm{i}}$ : the genotype effect with com $\mathrm{g}_{\mathrm{i}} \sim$ NID $\left(0, \phi_{g}\right)$

in which genotypes were fixed-effect factors $\mathrm{e}_{\mathrm{ij}}$ : the experimental error with $\mathrm{e}_{\mathrm{ij}} \sim \mathrm{NID}(0$, $\left.\sigma_{e}^{2}\right)$

For the simulation of this model, the value of environmental variance $\left(\sigma_{e}^{2}\right)$ was initially obtained the by the expression:

$$
\sigma_{e}^{2}=\left(\frac{C V}{100} \mu\right)^{2}
$$

Being:

$\mathrm{CV}$ : the coefficient of variation;

$\mu$ : the general mean.

With this value, repeatability was calculated by the following expression:

$$
r^{2}=\frac{\varphi_{g}}{\varphi_{g}+\frac{\sigma_{e}^{2}}{b}}
$$

Being:

$\varphi_{g}:$ the variance associated to the genotype;

$\sigma_{e}^{2}:$ the random error or variance associated with the environment;

b: the number of blocks.

A second alternative to calculate repeatability was the ratio $\frac{\sigma_{g}^{2}}{\varphi_{g}}$ as a variable $\mathrm{C}$ with value previously fixed. Thus, the phenotypic repeatability was represented by the expression: 


$$
r^{2}=\frac{1}{1+\frac{c}{b}}
$$

Based on the data used as reference for bean crop, $\mathrm{C}$ ratio was fixed by values 4,8 and 12 . Genotype $\left(\mathrm{g}_{\mathrm{i}}\right)$ and block $\left(\mathrm{b}_{\mathrm{j}}\right)$ effects were also simulated, which were obtained based on the cumulative normal distribution. The random variable value $Y_{i j}$ was generated with the blocks effects $\left(b_{j}\right)$, genotypes effects $\left(g_{i}\right)$ and environmental variance $\left(\mathrm{e}_{\mathrm{ij}}\right)$,

By using simulated data, analysis of variance was carried out to obtain the components of variance. Genotype means were arranged in an order, and the Spearman correlation was obtained between the estimated and true genotypic values. Since its application is based on the order of treatments, the true and estimated genetic value of the genotypes means were ranked In addition, superior genotypes selected for each scenario based on the estimated genetic value were compared with the estimated phenotypic values. Thus, the percentage of coincidence between the phenotypic and the genotypic selection was calculated.

For each of the 729 scenarios, 2000 experiments were simulated, from which the proportion of coincidence to select experiments with coefficient above and below $20 \%$ was calculated. This coincidence ratio ranged from $5 \%$ to $50 \%$, in intervals of $5 \%$.

\section{RESULTS AND DISCUSSION}

Figure 1 shows the values of the Spearman correlation coefficient between estimated phenotypic means and their true genotypic values for common bean in relation to repeatability. Regardless of the fixed genetic variation $\left(\mathrm{CV}_{\mathrm{G}}\right)$ and the number of individuals (genotypes) in the progeny, the Spearman correlation coefficient increased with the increase in repeatability $\left(\mathrm{r}^{2}\right)$, followed by decrease of the population CV. This fact is due to the restriction imposed by the simulation mechanism adopted in the experiment. (b)

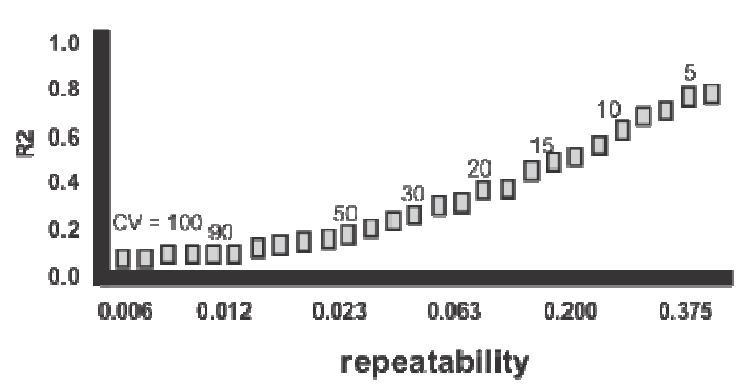

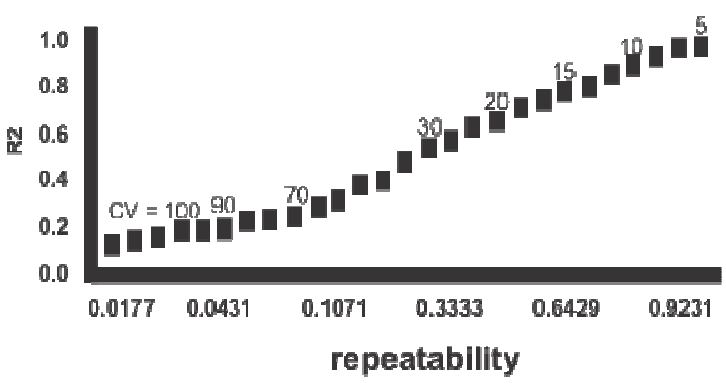

(c)

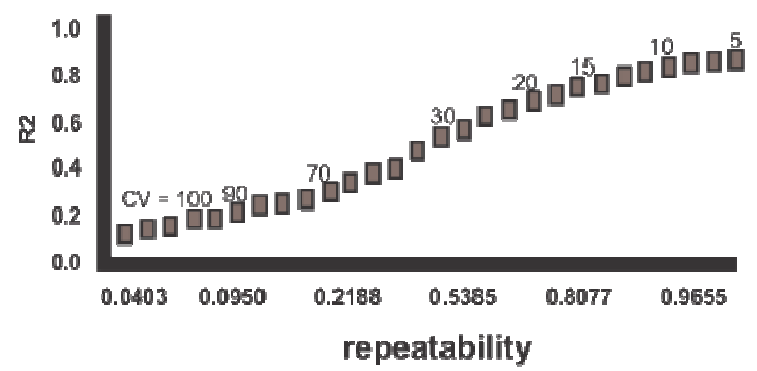

प26i Genotypes $\square 30$ Genotypes 136 Genotypes

Figure 1. Spearman correlation coefficient for common bean (Phaseolus vulgaris) in relation to repeatability for different coefficients of variation in experiment with different numbers of genotypes $(25,30$ and 36.), and for $\mathrm{CV}_{\mathrm{g}}$ equal to 5 (a), 15 (b) and 35 (c).

Cargnelutti Filho and Storck (2007) pointed out that the coefficient of environmental variation $\left(\mathrm{CV}_{\mathrm{e}}\right)$ and the least significant distance (LSD) are associated with the mean and with the residual variance, and are suitable statistics to evaluate the degree of accuracy of experiments with similar means. The authors also stated that higher values of heritability statistics, coefficient of determination, and the value of the $\mathrm{F}$ test for the cultivar are associated with higher genetic variability and lower 
residual variances. Consequently, these statistics methods do not depend on the mean of the test, and are suitable for measuring the degree of accuracy of experiments in general.

The proportion of coincidence of the $10 \%$ of individuals selected for common bean crops in relation to repeatability is illustrated in Figure 2. The greater the repeatability value, and the lower the population $\mathrm{CV}_{\mathrm{p}}$, the greater is the coincidence value. This observation does not depend on the number of individuals in the population, nor on the fixed $\mathrm{CV}_{\mathrm{g}}$.
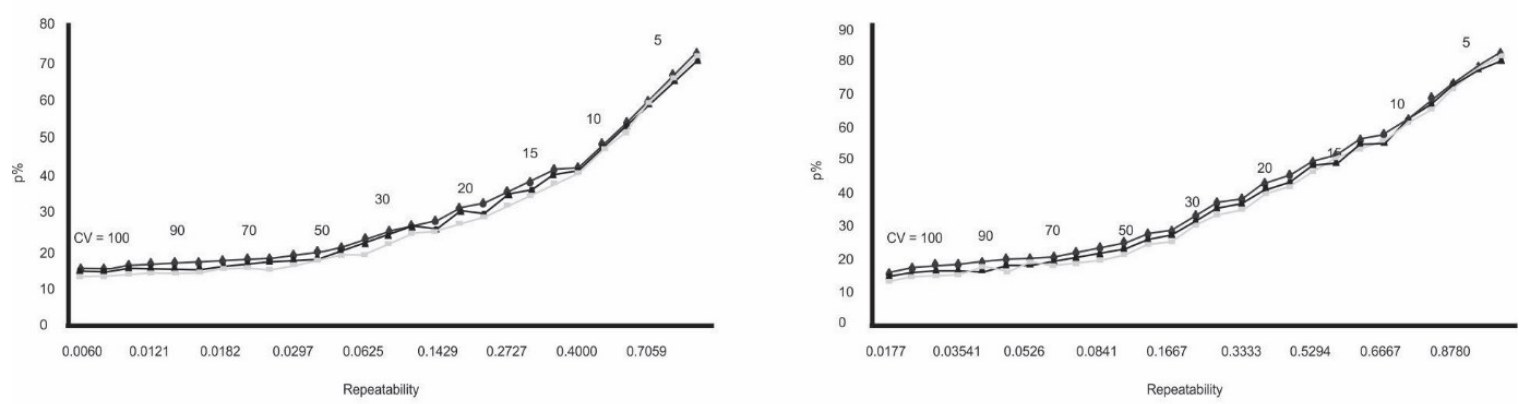

(c)

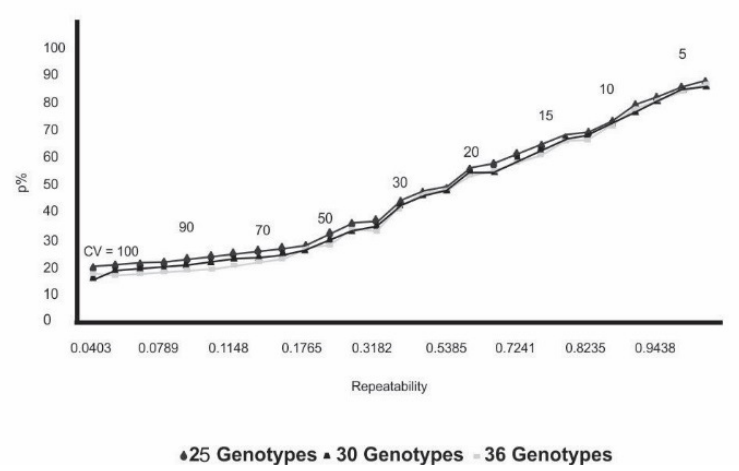

Figure 2. Proportion of coincidence of the $10 \%$ of genotypes selected for common bean crops, in relation to repeatability for different coefficients of variation in experiments with different numbers of genotypes (25, 30 and 36), and for $\mathrm{CV}_{\mathrm{g}}$ equal to 5 (a) 15 (b) and 35 (c).

In a breeding program, $\mathrm{CV}$ may inform the experimental quality of intermediate and final experiments of a specific culture. In these experiments, a set of variables is measured to assist the breeder in the description and recommendation of a new cultivar (CARVALHO et al., 2003). However, the CV is a statistics correlated with the mean, and it is useful only in cases of experiments with similar means (CARGNELUTTI FILHO; STORCK, 2007).

Figures 1 and 2 do not allow evaluating the efficiency of the CV as an estimator for discard or selection of individuals in a population of a breeding program, nor the evaluation of the cultivars to be recommended for cultivation. This occurs mainly because one cannot identify, in Figure 1, whether the increase in the Spearman correlation coefficient is due to an increase in repeatability or to a reduction in the population CV. Likewise, Figure 2 does not show whether the increase in the proportion of coincidence of the $10 \%$ selected was due to a reduction in the $\mathrm{CV}$ or to an increase in repeatability. Oliveira et al. (2009), evaluated the influence of $\mathrm{CV}$ on the experimental accuracy in common bean and concluded that $\mathrm{CV}$ is different among variables, since each variable has different genetic parameters, such as genetic variance and heritability, and consequently the experimental accuracy is different.

For this simulation system, when the value of $\mathrm{C}$ was fixed, repeatability did not alter with the increase in CV (Figure 3). When repeatability was kept unchanged and the CV was reduced, genetic variation increased with the increase in environmental variation. Thus, when the values of $\mathrm{C}$ were fixed, the population $\mathrm{CV}$ did not affect the repeatability value. However, changes in $\mathrm{r}^{2}$ reflected the change in the values of Ratio C. 


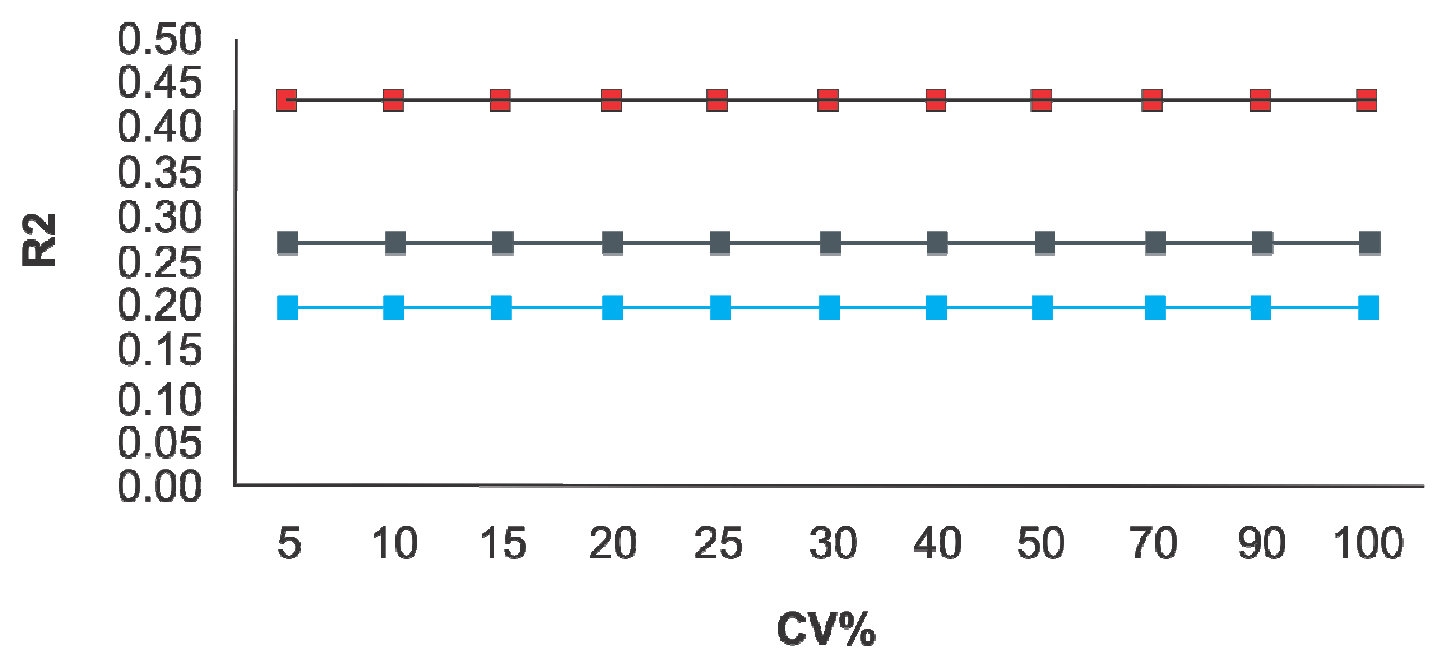

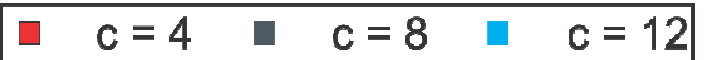

Figure 3. Repeatability for different coefficients of variation in three values of Ratio $\mathrm{C}$ for common bean crops (Phaseolus vulgaris). $\mathrm{R}^{2}$ is the coefficient of determination.

Spearman correlation coefficients $\left(\mathrm{r}_{\mathrm{S}}\right)$ were calculated in 25 individuals for three values of common bean mean yield $(\mathrm{kg} / \mathrm{ha})$ in different $\mathrm{CV}$

(a)

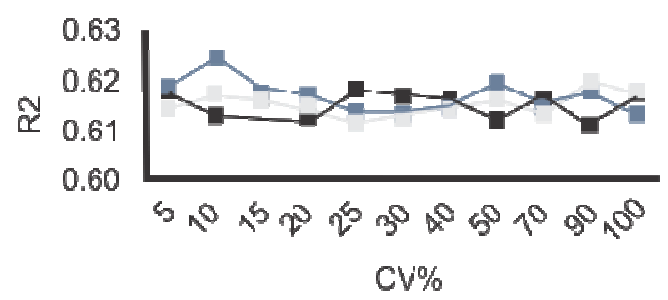

(Figure 4). Regardless of the CV, the values of the Spearman correlation coefficient remained in a similar range.

(b)

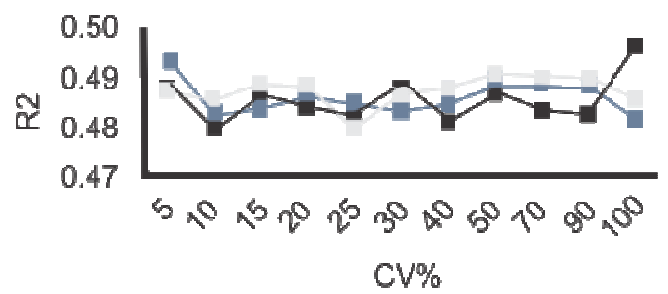

(c)

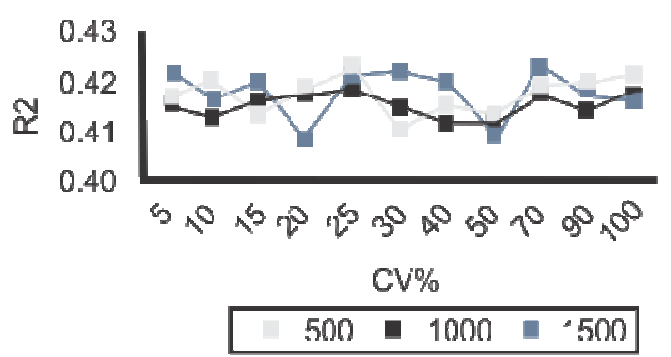

Figure 4. Spearman correlation coefficient $\left(\mathrm{r}_{\mathrm{S}}\right)$ for three values of mean yield $(\mathrm{kg} / \mathrm{ha})$ in common bean crops, in 11 coefficients of variation, in a population with 25 individuals, with ratio $C$ values of 4 (a) 8 (b) and 12 (c). $\mathrm{R}^{2}$ is the coefficient of determination.

Cargnelutti Filho and Storck (2007) stated that it is appropriate to establish the limits of classes of experimental accuracy of the statistics of the $\mathrm{CV}$ when they are based on the normal distribution and have similar means. However, Storck et al. (2010) concluded that the establishment of precise critical values using statistics as $\mathrm{CV}_{\mathrm{e}}$ and $\mathrm{LSD}$, which do not have good properties since they are based on phenotypic mean, does not help much on the classification of experimental accuracy. Thus, the development of more efficient methods to establish which experiments may or may not be used to calculate the value for cultivation and use (VCU) isparamount.

However, since the value of $\mathrm{C}$ was fixed, and repeatability estimates were obtained from it, an 
increase was observed in the Spearman correlation coefficient with the increase in $\mathrm{C}$, and consequently with the increase in repeatability. Results show that unlike the $\mathrm{CV}$, repeatability is the main responsible factor for the variation of the Spearman correlation.

The final step of cultivars evaluation in a breeding program depends largely on the efficiency of the breeder to use reliable parameters that can identify the most promising cultivars in experiments and that may have the same good performance in the field. Thus, the Spearman correlation and the $\mathrm{CV}$ may assist the breeder in decision making.

Besides the significance of the $F$ test for genotypes, the classification of the experiments by means of statistical experimental accuracy is crucial (CARGNELUTTI FILHO et al., 2012). The analysis of the experimental accuracy is important to guarantee that the results obtained in field experiments are reliable, and consequently the differences between genotypes are not due to the high experimental error. Therefore, experiments with high experimental error, which mislead to a low experimental accuracy (lower then 0.40), must be discarded (RESENDE et al., 2004).

The indiscriminate use of the $\mathrm{CV}$, regardless of the crop or of the response variable, is necessary for the identification of the optimal $\mathrm{CV}$ values for each trait (COSTA et al., 2002). Storck et al. (2010) evaluated 15 statistical methods, including $\mathrm{CV}$, in order to measure the experimental accuracy for soybean yield. The authors concluded that $\mathrm{CV}$ is not a criterion for the discard ofthe experiments.

According to Sprent and Smeeton (2016), by using the Lilliefors test, only mean, $\mathrm{R}^{2}, \mathrm{~h}^{2}$, and $\mathrm{D}$ adjusted were suitable to evaluate experiment quality for traits with normal distribution, out of the 16 statistics evaluated methods. The lack of normality for $\mathrm{CV}_{\mathrm{e}}$ was also observed in soybean experiments (CARVALHO et al. 2003). Moreover, in corn, Cargnelutti Filho and Storck (2007) found that $\mathrm{CV}_{\mathrm{e}}, \mathrm{LSD}$, and rank of means $(\mathrm{H})$ were suitable to evaluate experiments for traits with normal distribution, out of 14 statistical methods evaluated in the study. Thus, the occurrence of $\mathrm{CV}$ in a suitable value (lower than 20) to establish the limits of accuracy depends on the data set and on the culture. Conversely, the establishment of accurate critical values, which do not have good properties since they are calculated based on the trait's mean as $\mathrm{CV}$, does not increase the experimental accuracy. Cargnelutti Filho and Storck (2009) evaluated 12 statistical methods to be used as measures for the degree of experimental accuracy in corn experiments, and concluded that selective accuracy statistics, heritability, coefficient of determination and $F$ test value for the cultivar have direct relationship with each other, and they are more suitable than the $\mathrm{CV}$ and the least significant difference by the Tukey test.

Once proven that the $\mathrm{CV}$ is not a good parameter to be used in cultivars recommendations in experiments where the means are not similar, other criteria were used, so that breeders would make decisions with more certainty. Several authors have investigated improvements in experimental accuracy in common bean experiments in relation to the sample size of plants traits (CARGNELUTTI FILHO et al., 2008), to the use of borders in plots (RIBEIRO et al., 2001), and to the number of replications (CARGNELUTTI FILHO et al., 2009).

Repeatability was the most reliable criterion explaining the changes in the Spearman correlation coefficient between true and estimated means. The changes in the percentage of coincidence of the best genotypes observed in relation to the exact value were also explained by repeatability. This fact contrasts with the $\mathrm{CV}$, which, at any magnitude, had no significant influence on the changes in the Spearman correlation coefficient.

In a fixed population, $\mathrm{CV}$ increases with the increase in the environmental variance. This fact is due to controllable or uncontrollable effects. Genetic variation is fixed for the same population. Thus, repeatability will be reduced with the increase in the environmental variation. However, during simulation, these two quantities can be manipulated by using fixed repeatability. Fixed repeatability was performed in this study, and results show that it is the most important factor in the evaluation of the quality of an experiment. Experiment accuracy was measured by the correlation of the estimates of genotypic effects and the true genotypic values. When repeatability was maintained constant, little or no change was observed in the Spearman correlation. Nevertheless, an increase in repeatability led to a proportional increase in correlation between the phenotypic values and the true genotypic values.

Thus, repeatability estimate in experiments is important to help breeders make decisions on the estimate of a given parameter. Results suggest the restructuring of the criteria of the Minimum Requirements for Determining the Value for Cultivation and Use (VCU), so that new varieties can be registered in the National Registry of Cultivars. Besides being the last step in a breeding program, breeders should consider that the evaluation of cultivars constitutes a series of closely related steps. 


\section{CONCLUSION}

Coefficient of variation is not a good estimator for systematic discrimination and discard of experiments that the aim at cultivar recommendation. Conversely, repeatability is the parameter that will define the discard criteria of evaluation experiments and cultivar recommendation.

\section{ACKNOWLEDGMENTS}

The authors thank the Embrapa's researchers Antônio Carlos de Oliveira and Angela de Fátima Barbosa Abreu for providing data for the experiment; and CAPES, CNPq and FAPEMIG, for granting financial support and $\mathrm{PhD}$ scholarship.

RESUMO: A decisão de descartar um experimento envolve um grande desperdício de tempo e dinheiro e, portanto, e os experimentos de campo precisam ser desenvolvidos com a maior acurácia possível para que o melhorista não selecione genótipos inferiores. A simulação de um grande número de experimentos e características é a príncipal estratégia para ajudar os melhoristas na montagem dos experimentos. O objetivo deste trabalho foi avaliar dois critérios para verificar a eficiência de um experimento: Coeficiente de variação (CV) e coeficiente de repetibilidade. Dados de 104 experimentais de avaliação de linhagens de feijoeiro foram utilizados. Para a simulação dos experimentos, os seguintes parâmetros foram considerados: número de cultivares, número de blocos, variância genética, média de produtividade e coeficiente de variação. Foram simuladas 2000 repetições para cada cenário. As médias dos genótipos foram ordenadas e a correlação de Spearman entre os valores observados e os valores genotípicos reais foram obtidas. Os resultados revelaram que o CV não é um estimador confiável para a avaliação da qualidade do ensaio em experimentos de campo. Concluiu-se que o coeficiente repetibilidade é o parâmetro que possibilitará definir critérios mais precisos de descarte de experimentos de avaliação e recomendação de cultivares.

PALAVRAS-CHAVE: Phaseolus vulgaris. Cultivares. Precisão experimental. Métodos estatísticos

\section{REFERENCES}

CARGNELUTTI FILHO, A.; GONÇALVES, E.C.P. Estimativa do número de repetições para a avaliação de caracteres de produtividade e de morfologia em genótipos de soja. Comunicata Scientiae, v. 2, p. 25-33, 2011.

CARGNELUTTI FILHO, A.; MARCHESAN, E.; SILVA, L.S.; TOEBE, M. Medidas de precisão experimental e número de repetições em ensaios de genótipos de arroz irrigado. Pesquisa Agropecuária Brasileira, v. 47, p. 336-343, 2012. https://doi.org/10.1590/S0100-204X2012001000001 https://doi.org/10.1590/S0100204X2012000300004

CARGNELUTTI FILHO, A.; RIBEIRO, N. D.; STORCK, L.; JOST, E.; POERSCH, N. L. Tamanho de amostra de caracteres de cultivares de feijão. Ciência rural, v. 38, p. 635-642, 2008.

https://doi.org/10.1590/S0103-84782008000300007

CARGNELUTTI FILHO, A.; STORCK, L. Estatísticas de avaliação da precisão experimental em ensaios de cultivares de milho. Pesquisa Agropecuária Brasileira, v. 42, p. 17-24, 2007. https://doi.org/10.1590/S0100204X2007000100003

CARGNELUTTI FILHO, A.; STORCK, L. Medidas do grau de precisão experimental em ensaios de competição de cultivares de milho. Pesquisa Agropecuária Brasileira, v. 44, p. 111-117, 2009. https://doi.org/10.1590/S0100-204X2009001000003 https://doi.org/10.1590/S0100-204X2009000200001

CARGNELUTTI FILHO, A.; RIBEIRO, N.D.; STORCK, L. Número de repetições para a comparação de cultivares de feijão. Ciência Rural, v. 39, p. 2419-2424, 2009. https://doi.org/10.1590/S010384782009000900006 https://doi.org/10.1590/S0103-84782008005000059

CARVALHO, C. G. P.; ARIAS, C. A. A.; TOLEDO, J. F. F.; ALMEIDA, L. A.; KIIHL, R. A. D. S.; OLIVEIRA, M. F.; HIROMOTO, D. M.; TAKEDA, C. Proposta de classificação dos coeficientes de variação 
em relação à produtividade e altura da planta de soja. Pesquisa Agropecuária Brasileira, v. 38, p. 187-193, 2003. https://doi.org/10.1590/S0100-204X2003000200004

CASQUERO, P. A.; LEMA, M.; SANTALLA, M.; RON, A. M. Performance of common bean (Phaseolus vulgaris L.) landraces from Spain in the Atlantic and Mediterranean environments. Genetic Resources and Crop Evolution, v. 53, p. 1021-1032, 2006. https://doi.org/10.1007/s10722-004-7794-1

CATAPATTI, T. R.; GONÇALVES, M. C.; SILVA NETO, M. R.; SOBROZA, R. Tamanho de amostra e número de repetições para avaliação de caracteres agronômicos em milho-pipoca. Ciência e Agrotecnologia, v. 32, p. 855-862, 2008. https://doi.org/10.1590/S1413-70542008000300023

CONAB - Companhia Nacional De Abastecimento. 2016. Acompanhamento da safra brasileira de grãos 2015/2016.

(http://www.conab.gov.br/OlalaCMS/uploads/arquivos/16_01_12_09_00_46_boletim_graos_janeiro_2016.pdf) . Accessed on 04/09/2017.

COSTA, N.; SERAPHIN, J. C.; ZIMMERMANN, F. J. P. Novo método de classificação de coeficientes de variação para a cultura do arroz de terras altas. Pesquisa Agropecuária Brasileira, v. 37, p. 243-249, 2002. https://doi.org/10.1590/S0100-204X2002000300003

LIMA, J. F.; PEIXOTO, C. P.; LEDO, C. A. D. S.; FARIA, G. A. Tamanho ótimo de parcela para experimentos com plantas de mamoeiro em casa de vegetação. Ciência e agrotecnologia, v. 31, p. 1411-1415, 2007. https://doi.org/10.1590/S1413-70542007000500021

MARTIN, T. N.; DUTRA, L. M. C.; JAUER, A.; STORCK, L.; ZABOT, L.; UHRY, D.; SANTI, A. L.; STEFANELO, C.; LUCCA FILHO, O.A. Tamanho ótimo de parcela e número de repetições em soja (Glycine $\max$ (L.) Merril). Ciência Rural, v. 35, p. 271-276, 2005. https://doi.org/10.1590/S0103-84782005000200004

OLIVEIRA, R. L.; MUNIZ, J. A.; DE ANDRADE, M. J. B.; DOS REIS, R. L. Precisão experimental em ensaios com a cultura do feijão. Ciência e agrotecnologia, v. 33, p. 113-119, 2009.

https://doi.org/10.1590/S1413-70542009000100016

OLIVEIRA, S. J. R.; STORCK, L.; LÚCIO, A. D.; LOPES, S. J.; MARTINI, L. F. D. Índice de heterogeneidade, coeficiente de variação e tamanho ótimo de parcela em batata. Ciência Rural, v. 36, p. 17101716, 2006. https://doi.org/10.1590/S0103-84782006000600007

RAMALHO, M. A. P.; FERREIRA, D. F.; OLIVEIRA, A. C. Experimentação em genética e melhoramento de plantas. Lavras: UFLA, 2005. 322p.

RESENDE, M. D. V.; SILVA, F. F.; AZEVEDO, C. F. Estatística Matemática, Biométrica e Computacional: modelos mistos, multivariados, categóricos e generalizados (REML/BLUP), inferência bayesiana, regressão aleatória, seleção genômica, QTL-GWAS, estatística espacial e temporal, competição, sobrevivência. Visconde do Rio Branco: Suprema, 2014. 881p.

RIBEIRO, N. D.; STORCK, L.; MELLO, R. M. Bordadura em ensaios de competição de genótipos de feijoeiro relacionados à precisão experimental. Ciência Rural, v. 31, p. 13-17, 2001. https://doi.org/10.1590/S010384782001000100003

SPRENT, P.; SMEETON, N. C. Applied nonparametric statistical methods. Boca Raton: CRC Press, 2016. 526 .

STORCK, L.; CARGNELUTTI FILHO, A.; LÚCIO, A. D.; MISSIO, E. L.; RUBIN, S. Avaliação da precisão experimental em ensaios de competição de cultivares de soja. Ciência e Agrotecnologia, v. 34, p. 572-578, 2010. https://doi.org/10.1590/S1413-70542010000300007 
Repeatability reveals...

GURGEL, F. L. et al.

STORCK, L.; LOPES, S. J.; MARQUES, D. G.; TISOTT, C. A.; ROS, C. A. Análise de covariância para melhoria da capacidade de discriminação em ensaios de cultivares de milho. Pesquisa Agropecuária Brasileira, v. 35, p. 1311-1316, 2000. https://doi.org/10.1590/S0100-204X2000000700004

ZILIO, M.; COELHO, C. M. M.; SOUZA, C. A.; SANTOS, J. C. P.; MIQUELLUTI, D. J. Contribuição dos componentes de rendimento na produtividade de genótipos crioulos de feijão (Phaseolus vulgaris L.). Revista Ciência Agronômica, v. 42, p. 429-438, 2011. https://doi.org/10.1590/S1806-66902011000200024 